Agro-Science Journal of Tropical Agriculture, Food, Environment and Extension Volume 18 Number 3 (September 2019) pp. 35-41

ISSN 1119-7455

\title{
OPTIMUM PRODUCTION PLAN FOR MAIZE-BASED CROP FARMERS IN NIGER STATE, NIGERIA
}

\author{
"Ibrahim F.D., Oformata A.O., Jirgi A.J. and Adewumi A. \\ Department of Agricultural Economics \& Farm Management, \\ Federal University of Technology, PMB 65, Minna, Niger State, Nigeria \\ *Corresponding author's email: idfaith006@yahoo.com
}

\begin{abstract}
The study tried to address optimum production plan for maize-based crop farmers in Niger State, Nigeria. Primary data were collection with the aid of a structured questionnaire. Simple random sampling technique was used in selecting a total of 133 farm households engaged in maize-based crop production. The results showed that maize-based arable crop production in the study area is predominantly male activity, with a mean age of 37 years. The average household size of the respondents was 5 persons. Majority (86.46\%) of the farmers had one form of formal education ranging from tertiary, primary, secondary and adult education. Also, $81.95 \%$ of the farmers earned less than $\$ 100,000$ per annum from off-farm activities. An average farmer had 20 years of farming experience and cultivated 1.88 ha of land. Linear programming solution prescribed maize/soybeans on 1.1988 ha and maize/cowpea on 0.0468 ha respectively in the optimum farm plans for the farmers. It also indicated gross margin could be increased from $\$ 120,122.73 \mathrm{ha}^{-1}$ in the existing crop production plan to $\$ 211,555.70 \mathrm{ha}^{-1}$ in the prescribed optimum crop production plan. It was concluded that production inputs were not optimally utilized and that crop mixtures were in a better competitive position than sole crop to increase the farmers' income in maize-based crop production systems in Niger State. It was recommended that farmers should produce crop mixtures maize/soybeans and maize/cowpea based on their hectarage allocation as prescribed in the optimum farm plans and that farm advisory services should give attention to optimum cropping patterns towards promoting increased agricultural productivity among farmers.
\end{abstract}

Key words: linear programming, sole crop, crop mixtures, income

\section{INTRODUCTION}

According to NBS (2012), over $60 \%$ of the Nigerian population is employed by agriculture; the sector contributes about $40 \%$ to the Nigerian Gross Domestic Product (GDP). Maize is a staple food crop that is popularly grown in many of the Sub-Saharan countries of Africa including Nigeria, with per capita consumption of $40 \mathrm{~kg} /$ year (WHO and FAO, 2003). The crop has significant impact in the economics of developed and developing countries. Despite the economic importance of maize crop to the country, its supply cannot meet the demand of the teeming population. Ogundari and Ojo (2007) stated that Nigeria population is estimated to be growing at $3.2 \%$ per annum while agricultural production is growing at $2.5 \%$ per annum. Hence, this creates demand-supply imbalance of food in the country. USDA (2012) stated that in 2011, 5.15 million hectares were cultivated to maize, with a production of 9.25 million tons per annum, giving a yield of 1.8 tons per hectare. CBN (2007) stated that in Nigeria, the food demand-supply deficit has caused the country to increase its import bill from N160.2 billion in 2001 to N290.7 billion in 2007. By the same vein, maize domestic demand of 3.5 million tons outstrips supply of 2.0 million tons per annum. Ojo (2003) reported that factors such as price fluctuation, diseases and pests, poor storage facilities have been associated with low maize production in the country. Hence, there is inadequate availability of maize as food to humans, poultry producers and feed millers are unable to get sufficient corn supplies from local sources and are therefore looking to imports. USDA (2012) stated that because of the need to import maize in order to meet the local demand, import ban on corn was lifted in 2008 and allowed at 5\% tariff. Maize based intercropping system is currently receiving global attention because of its prime importance in World Agriculture. Usually, cereals such as maize, millet and sorghum are often intercropped with leguminous crops like beans, cowpea, groundnut, pigeon pea and soyabean. In fact, this is the dominant food production system in East Africa. Subbarao et al. (2000) stated that in West Africa, cereals such as maize, pearl, millet and sorghum are traditionally intercropped with cowpea. Chukwuji (2008) stated that maize is grown with crops like cassava, melon, vegetable and yam. The 
author further stated that traditionally an average of three to five crops are combined and best combinations gives the farmer desired result there by raising the income level of the farmer. Kariaga (2004) demonstrated that the practice of planting maize as a sole crop is not sustainable and recommended that farmers should be encouraged to intercrop maize with other low legumes such as cowpea and soybeans so that the nation does not suffer from food shortages. Seran and Brintha (2010) also stated that intercropping is an attractive strategy to smallholder farmers for increasing productivity, farmer's income level and land labour utilization per unit of area of available land though intensification of land use. Taking the aforementioned into cognizance, farm planning has therefore become an important task to be given due attention so that the farmers could be guided into making optimum crop production decisions. According to Sarker and Quaddus (2002), crop planning involves making decisions on the best crops to cultivate and the production system to adopt given the available production inputs.

Optimization implies looking for the decision which gives the best possible value of some measures of performance from amongst the set of possible decisions. Optimal crop pattern and production of food crops with maximum profit is important information for agricultural planning using optimization methods. Several optimization techniques such as Linear Programming (LP), Dynamic Programming (DP) and Genetic Algorithm (GA) have been applied in agriculture. However, the LP model as an analytical tool for studying the economic aspects of farm management is more popular because of the proportionate characteristic of the allocation problems (Wankhade and Lunge, 2012; Sofi et al., 2015). Its technique has been used to study the problems of resource allocation among farmers and in the present stage of development focuses on deriving optimum production plans for farmers. LP provides the maximizing net returns from a combination of enterprises under given conditions of resource restriction. Singh (2009) stated that Information on the optimal allocation of resources as to what crop activities to undertake, how much land to allocate among competing crop activities and what method and combinations of inputs to use on each crop activity so that net farm incomes are maximized is crucial to the farmer. Identifying the best farm plan is a difficult task for smallholder crop farmers who are characterized with low literacy and resources levels. These farmers often make farm planning decisions by trial and error method which often results in uncertain outcomes. In Niger State, many studies have been done on the economics of arable crop production. Most of these studies focused on production function analysis, profitability, efficiency and adoption of improved technologies but failed to solve the problems of optimum crop enterprise combinations under given conditions. It is against this backdrop that this study sought to provide optimum production plan for maize-based crop farmers in Niger State. It specifically sought to describe the socio-economic characteristics of respondents, identify the existing maize-based crop enterprises undertaken by the farmers, and determine the optimum maize-based cropping plans for maximum income in the study area. The place of optimum farm plans for the farmers cannot be over emphasized as it provides a valuable guide to both new entrants and practicing farmers. Hassan et al. (2005) stated that farmers' profit cannot be maximized without optimum farm plan, which ensures efficient utilization of available resources. Information emanating from this study could be of benefit to agricultural decision makers and managers in both private and public firms who may need vital information on the best possible alternative crop combination that give highest level of returns. Agricultural researchers and students will also benefit from this study as its output will provide basis for further research on the subject matter in the area.

\section{MATERIALS AND METHODS}

\section{The Study Area}

Niger State has 25 local government areas. It lies between Latitudes $8^{\circ} 22^{\prime} \mathrm{N}$ and $11^{\circ} 30^{\prime} \mathrm{N}$ and Longitudes $3^{\circ} 30^{\prime} \mathrm{E}$ and $7^{\circ} 20^{\prime} \mathrm{E}$. Kaduna State and F.C.T Abuja boarder the State to the North-East and South-East, respectively; Zamfara State borders the state to the North, Kebbi State to the West, Kogi State to the South, Kwara State to the South-West, and the Republic of Benin to the North -West (National Bureau of Statistics, 2015). The State has a total land area of $74,244 \mathrm{~km}^{2}$ which makes it the largest state in the country (Alhassan, 2017). Several ethnic groups are found in the State. The 2006 population census put the population figure of the State at 3,950,249 persons consisting of 2,032,725 males and 1,917, 524 females (NPC, 2006). The population of the state for 2015 as projected by the United Nations Population Fund (UNFPA) is 5,337,148 (UNFPA, 2015). Niger State has distinct dry and wet seasons with annual rainfall varying from $1,100 \mathrm{~mm}$ in the northern part to $1,600 \mathrm{~mm}$ in the southern part. Its maximum temperature of about $37^{\circ} \mathrm{C}$ is recorded between March and June; while the minimum is usually $21^{\circ} \mathrm{C}$ between December and January. The rainy season lasts for about 150 days in the southern parts to about 120 days in the northern parts of the State. The soils are fertile and the hydrology permits the cultivation of most of Nigeria's staple crops and still allows sufficient opportunities for grazing and fresh water fishing. Mineral resources such as gold, clay, silica, sand, Kyanite, Mable, Copper, Iron, Feldspars, Lead, Columbite, kaolin 
and tantalite are also found in the State (Niger State Ministry of Information, 2014). Most of the communities in Niger State are predominantly agrarian; the types of crops grown include sugar cane, vegetables, groundnut, soya beans, rice, melon, cassava, sorghum, maize, millet, Shea butter, yam, cotton and cowpea. The major tree crops cultivated are mango, citrus, coconut, cashew, banana and pawpaw. The inhabitants of the State also rear livestock like cattle, sheep, goats and chicken among others.

\section{Sampling Procedure}

A multi-stage sampling procedure was used. The first stage involved the use of simple random technique in selecting two local government areas (LGAs) from each of the three zones in the state making a total of six LGAs. The second stage involved the use of simple random technique in selecting two villages from each local government area making a total of twelve villages. The third stage involved proportionate selection of ten percent of the maize-based crop farmers from each village and this gave a total of one hundred and thirty-three farmers in all from a sample frame of one thousand, three hundred and twenty-seven. Data for the study were primary data collected with the aid of structured questionnaire.

\section{Analytical Techniques}

Descriptive statistics was used in describing the socio-economic characteristics of the respondents and linear programming was used to determine the optimum farm plans for maximum resource allocation for farmers. The model used for determining the optimum farm plans can be expressed by the equation:

Objective function:

$$
\begin{gathered}
\text { Maximize } \quad Z=p_{1} x_{1}+p_{2} x_{2}+p_{3} x_{3}+ \\
\ldots .+p_{8} x_{8}
\end{gathered}
$$

Subject to:

$$
\begin{aligned}
A_{11} X_{1}+A_{12} X_{2}+ & A_{13} X_{3}+\ldots .+A_{18} X_{8} \\
& \leq L_{S}(\text { Land }) \\
A_{21} X_{1}+A_{22} X_{2}+ & A_{23} X_{3}+\ldots .+A_{28} X_{8} \\
& \leq H_{t}(\text { Labour }) \\
A_{31} X_{1}+A_{32} X_{2}+ & A_{33} X_{3}+\ldots .+A_{38} X_{8} \\
& \leq C_{t}(\text { Capital }) \\
A_{41} X_{1}+A_{42} X_{2}+ & A_{43} X_{3}+\ldots .+A_{48} X_{8} \\
& \leq L_{S}(\text { Seed }) \\
A_{51} X_{1}+A_{52} X_{2}+ & A_{53} X_{3}+\ldots .+A_{58} X_{8} \\
& \leq H_{t}(\text { Fertilizer }) \\
A_{61} X_{1}+A_{62} X_{2}+ & A_{63} X_{3}+\ldots .+A_{68} X_{8} \\
& \leq C_{t}(\text { Agrochemical })
\end{aligned}
$$

and

$X_{1} \geq 0, X_{2} \geq 0, X_{3} \geq 0, \ldots ., X_{8} \geq 0$

where;
Z - Gross Margin ( $/$ ha), $X_{1}, X_{2}, X_{3}, \ldots X_{8}$ Different crop activities or enterprises undertaken (decision variables), $P_{1}, P_{2}, P_{3}, \ldots P_{8}$ - Output coefficients (gross margin) per hectare of the different crop activities maximized, $A_{i j}$ - InputOutput coefficient (quantity of $i^{\text {th }}$ resource (land, labour, capital, seed, fertilizer, and agrochemical) required to produce a unit output of $j^{\text {th }}$ crop activity, $L_{s}$ - Level of available land in hectare for crop activities with s restriction, $\mathrm{m} H_{t}$ - Level of available labour in man-day for crop activities in $t^{\text {th }}$ period, $C_{t}$ - Level of available working capital in Naira for crop activities in $t^{\text {th }}$ period, $S_{t}$ - Level of available seed in kilograms for crop activities in $t^{\text {th }}$ period, $F_{t}$ - Level of available fertilizer in kilograms for crop activities in $t^{\text {th }}$ period, $A_{t}$ - Level of available agrochemical in litres for crop activities in $t^{\text {th }}$ period.

\section{RESULTS AND DISCUSSION}

Socio-Economic Characteristics of Respondents The socio-economic characteristics of maize-based farmers are presented in Table 1. The Results show that the highest percentages of the respondents $(66 \%)$ were between the ages of 31 and 40 while $33 \%$ were between 21 and 30 years of age. The mean age of all respondents was 37 years. This shows that arable farming activity in the study area was undertaken by farmers in their mid and active age. This is in agreement with the findings of Igwe et al. (2013) that farmers within this age can readily provide physical strength required for farming activities. Respondents were asked to indicate their household size which comprise of number of wives, children and dependants (if any), $58.65 \%$ reported a household size of between 1 and 5 persons while $39.85 \%$ indicated that they had a household size of between 6 and 10 persons. The mean household size was 5 . This shows that maizebased farmers in the study area had a relatively low household size which they cannot easily take advantage of as a source of adequate labour. This finding is not in agreement with the findings of Nasiru et al. (2012) in which $51.7 \%$ of the respondents had household size of 10 to 19 members while $15 \%$ had household size of 20 members and above. Results further indicated that a greater proportion of the respondents $(43.61 \%)$ had a farming experience of between 11 to 20 years while $30.83 \%$ reported a farming experience of 21 to 30 years, with an average farming experience of 20 years as shown in Table 1. This result agrees with that of Mafimisebi et al. (2013) in which the authors reported that only $9.2 \%$ of respondents had farming experience of 5 years or less. Majority of them (35\%) had farming experience of more than 20 years. The result presented in Table 1 shows that majority of the farmers $(99.25 \%)$ were male and $0.75 \%$ were female. This is an indication that the males are the 
Table 1: Socio-economic characteristics of the respondents

\begin{tabular}{|c|c|c|c|}
\hline Variable & $\begin{array}{c}\text { Frequency } \\
(n=133)\end{array}$ & Percentage & Mean \\
\hline \multicolumn{4}{|l|}{ Sex } \\
\hline Male & 132 & 99.25 & \multirow{8}{*}{37.00} \\
\hline Female & 1 & 0.75 & \\
\hline Age (Years) & & & \\
\hline $21-30$ & 33 & 24.81 & \\
\hline $31-40$ & 66 & 49.62 & \\
\hline $41-50$ & 28 & 21.05 & \\
\hline $51-60$ & 5 & 3.76 & \\
\hline Above 60 & 1 & 0.75 & \\
\hline \multicolumn{4}{|l|}{ Marital status } \\
\hline Single & 11 & 8.27 & \\
\hline Married & 121 & 90.98 & \\
\hline Divorced & 0 & 0.00 & \\
\hline Widowed & 1 & 0.75 & \\
\hline \multicolumn{4}{|l|}{ Level of education } \\
\hline No formal education & 18 & 13.54 & \\
\hline Primary education & 47 & 34.96 & \\
\hline Adult education & 2 & 1.50 & \\
\hline Secondary education & 23 & 17.29 & \\
\hline Tertiary education & 43 & 32.71 & \\
\hline \multicolumn{3}{|c|}{ Household size (Number) } & \multirow[t]{5}{*}{5.00} \\
\hline $1-5$ & 78 & 58.65 & \\
\hline $6-10$ & 53 & 39.85 & \\
\hline $11-15$ & 1 & 0.75 & \\
\hline \multirow{2}{*}{\multicolumn{3}{|c|}{ Farm size $(\mathrm{Ha})$}} & \\
\hline & & & \multirow[t]{4}{*}{1.88} \\
\hline $0.01-1.00$ & 57 & 42.86 & \\
\hline $1.01-2.00$ & 48 & 36.09 & \\
\hline Above 2.00 & 28 & 21.05 & \\
\hline \multicolumn{3}{|c|}{ Farming experience (Years) } & \multirow[t]{5}{*}{20.00} \\
\hline $1-10$ & 20 & 15.04 & \\
\hline $11-20$ & 58 & 43.61 & \\
\hline $21-30$ & 41 & 30.83 & \\
\hline Above 30 & 14 & 10.53 & \\
\hline \multicolumn{3}{|c|}{ Annual off-farm income $(\aleph)$} & \multirow[t]{5}{*}{$13,684.21$} \\
\hline $1-100,000$ & 109 & 81.95 & \\
\hline $100,001-200,000$ & 20 & 15.04 & \\
\hline $200,001-300,000$ & 2 & 1.50 & \\
\hline $300,001-400,000$ & 2 & 1.50 & \\
\hline
\end{tabular}

dominant maize farmers in the study area. This is in line with Angha and Itari (2012) who reported that males dominated cropping activities in Nigeria. The marital status of respondents as presented in Table 1 shows that $90.98 \%$ of the farmers were married while $8.27 \%$ were single. This result is similar to the findings of Akpan et al. (2012) who found that majority of farmers in Akwa Ibom State were married. Table 1 depicts the level of education of sampled maize-based farmers. Only $13.54 \%$ had no formal education, the remaining $86.46 \%$ had one form of formal education or the other ranging from adult $(1.50 \%)$, primary $(34.96 \%)$, secondary (17.29\%) and tertiary education $(32.71 \%)$. This implies that majority of those involved in maize-based crop farming are educated and hence are able to enhance their farming skills by adopting new innovations without much resistance thereby improving their profitability and general living standards. Sallawu (2014) reported a similar result in which majority of maize farmers in Delta State had primary, secondary and tertiary education.
The distribution of respondents according to farm size is depicted in Table 1 . The results show that $42.86 \%$ of the respondents had farm sizes ranging between $0.1-1.0$ hectares, while $36.09 \%$ of the respondents had farm sizes ranging between 1.12.0 hectares. The mean farm size in the area was found to be 1.88 hectares. This implies that majority of the maize-based crop farmers in the study area were small farm holders. This agrees with the finding of Fasasi (2007), who reported that highest percentage of food produced in Nigeria comes from small scale farmers. Results in Table 1 further revealed that $81.95 \%$ of the respondents earned less than $\$ 100,000$ as annual off-farm income, while the average annual off-farm income of the farmers was estimated to be $\$ 13,684.21$. This agrees with the findings of Akpan et al. (2012) that most arable crop farmers are low income earners.

Existing Crop Combination in the Study Area

The result presented in Table 2 shows the existing crop combinations under maize-based cropping system in Niger State. The result identified eight cropping activities in the study area. It revealed that only $21.80 \%$ of the respondents cultivated maize as a sole crop while the remaining $79.20 \%$ of the respondents cultivated maize as mixtures with other crops. The crops cultivated as mixtures in the study area comprised cereals and legumes which include maize/rice, maize/sorghum, maize/millet, maize/soybeans, maize/groundnut, maize/bambaranut and maize/cowpea respectively. On all the crop mixtures, maize/sorghum (27.82\%) and maize/groundnut $(17.29 \%)$ were the most cultivated by the respondents respectively while maize/bambaranut was the least cultivated.

\section{Determination of Optimum Farm Plans in the Study Area}

The optimization result which shows the optimum cropping activities, the shadow prices of the excluded activities, factors limiting the profit maximization objective, difference in existing and optimum plans in the study area are presented in Tables 3, 4, 5 and 6, respectively.

\section{Cropping Pattern in the Existing and Optimum Farm Plans}

The cropping pattern in the existing and optimum farm plans is presented in Table 3. The results prescribed 1.1988 ha for maize/soybeans and 0.0468 ha for maize/cowpea which are all crop mixtures. This implies that maize crop mixtures are in better competitive position to yield more than maize sole cropping in the study area. This finding supports Oviasogie (2005) who reported that mix cropping enterprise was more productive than sole cropping and gave higher return. 
Table 2: Distribution of respondents according to combination adopted

\begin{tabular}{lcc}
\hline Cropping combination & Frequency & Percentage \\
\hline Sole crop & & \\
Maize & 29 & 21.80 \\
Crops mixtures & 7 & 5.26 \\
Maize/Rice & 37 & 27.82 \\
Maize/Sorghum & 8 & 6.02 \\
Maize/Millet & 19 & 14.29 \\
Maize/Soybeans & 23 & 17.29 \\
Maize/Groundnut & 4 & 3.01 \\
Maize/Bambaranut & 6 & 4.51 \\
Maize/Cowpea & 133 & 100.00 \\
Total &
\end{tabular}

Source: Computed from field survey data, 2016

Table 3: Cropping pattern in the existing and optimum farm plans

\begin{tabular}{lcc}
\hline Cropping pattern & $\begin{array}{c}\text { Existing plan } \\
\text { (ha) }\end{array}$ & $\begin{array}{c}\text { Optimum plan } \\
\text { (ha) }\end{array}$ \\
\hline Maize & 1.4432 & - \\
Maize/Rice & 2.8235 & - \\
Maize/Sorghum & 2.3311 & - \\
Maize/Millet & 2.0000 & - \\
Maize/Soybeans & 1.7500 & 1.1988 \\
Maize/Groundnut & 1.4167 & - \\
Maize/Bambaranut & 1.7000 & - \\
Maize/Cowpea & 0.5000 & 0.0468 \\
\hline
\end{tabular}

Source: Data Analysis, 2016

Note: - Excluded crop activities

\section{Shadow Prices of Excluded Activities}

Shadow prices are marginal returns to investments of available resources. In a maximization problem, they are income penalties indicating the amount by which farm income would be reduced if any of the excluded activities is forced into the programme.

The result presented in Table 4 shows the various shadow prices of the excluded crop activities from the optimal production plan for the maize based crop farmers in Niger State. In a maximization LP problem, shadow prices are the income penalties indicating the amount by which farm income would be reduces if any of the excluded activities is forced into the programme. The result showed that 6 activities were excluded from the programme with maize/rice crop mixture having the highest shadow price of $\$ 73,955.30$ and followed by maize as a sole crop with shadow price of $\$ 67,927.62$. This implies that if these activities are forced into the programme or undertaken, the value of the objective function will be reduced by the values of their respective shadow prices, that is, $773,955.30$ and $\$ 67,927.62$ as they have the highest propensity to depress profit as prescribed by the programme. Same applies to other excluded activities.
Table 4: Shadow price of excluded activities in profit maximizing objective of maize based crop farmers in the study area

\begin{tabular}{llc}
\hline S/No & Excluded Activities & $\begin{array}{c}\text { Shadow Prices } \\
(\mathrm{A})\end{array}$ \\
\hline 1 & Maize & $67,927.62$ \\
2 & Maize/Rice & $73,955.30$ \\
3 & Maize/Sorghum & $40,441.95$ \\
4 & Maize/Millet & $47,520.21$ \\
5 & Maize/Groundnut & $30,530.20$ \\
6 & Maize/Bambaranut & $25,319.16$ \\
\hline \multicolumn{2}{l}{ Source: Data Analysis, 2016 }
\end{tabular}

Maize/bambaranut mixture however has the least shadow price of $25,319.16$. It thus means that maize/bambaranut is a better crop mixture in the programme compared to other excluded activities. It also means that this mixture would have been the next activity to be included in the optimal plan since it decreased the value of the objective function by the least amount on a comparative basis.

\section{Factors Limiting the Achievement of Profit Maximization Objective}

The factors limiting the achievement of the profit maximization objective in the study area as obtained from the LP output are presented in Table 5. The result showed that labour and capital were used up by the programme and had shadow prices of $1,076.90$ and $\$ 2.75$ respectively. This implies that labour and capital were therefore the limiting resources in maize based cropping system in the study area as they constrained the attainment of the profit maximization objective. It further implies that an increase in these resources by a unit will lead to an increase in the optimal profit by the values of their respective shadow prices. This agreed with the findings of Ismail (2013), who discovered that capital was the most limiting factor in the study area.This further agreed with the findings of Hassan et al. (2005), who opined that efficient and full utilization of resources leads to maximization of output. The resources that were surplus were land, seed, fertilizer and agrochemical as they were not used up by the programme. With zero shadow prices, the result shows that these resources were in excess of the actual requirements by the maize crop farmers in the study area and were therefore non-limiting. Any resource that was not used up was not a limiting resource and has a zero shadow price as it does not constraint the attainment of a programme's objective and vice versa (Olayemi and Onyenweaku, 1999).

Table 5: Marginal value product of resources

\begin{tabular}{llll}
\hline Resource & Use Status & Slack/Surplus & Shadow price (N) \\
\hline Land & Not Fully Utilized & 0.6944 & 0 \\
Labour & Fully Utilized & 0 & $1,076.906$ \\
Seed & Not Fully Utilized & 244.1374 & 0 \\
Capital & Fully Utilized & 0 & 2.7501 \\
Fertilizer & Not Fully Utilized & 7.9096 & 0 \\
Agro chemical & Not Fully Utilized & 0.9213 & 0 \\
\hline
\end{tabular}

Source: Data Analysis, 2016 
Table 6: Gross margin ( $\mathrm{N} / \mathrm{ha}$ ) in existing and optimum farm plans in the study area

\begin{tabular}{llll}
\hline $\begin{array}{l}\text { Gross Margin } \\
\text { for existing } \\
\text { plan }(\mathrm{N})\end{array}$ & $\begin{array}{l}\text { Gross Margin } \\
\text { for optimum } \\
\text { plan (N) }\end{array}$ & $\begin{array}{l}\text { Increase } \\
\text { over existing } \\
\text { plan (N) }\end{array}$ & $\begin{array}{l}\text { Increase } \\
\text { percent- } \\
\text { age }\end{array}$ \\
\hline $120,122.73$ & $211,555.70$ & $91,432.97$ & $76.12 \%$ \\
\hline
\end{tabular}

Source: Data Analysis, 2016

\section{Comparison of Gross Margin (\$/ha) in Existing and Optimum Farm Plans}

The results in Table 6 indicated that the gross margin in Naira per hectare in the existing plan from Table 3 was $\$ 120,122.73$ while in the optimum plan it was $\$ 211,555.70$. This depicts that there is a $76.12 \%$ increase in the optimum plan as compared to the existing plan. The implication of this is that, an average maize farmer in the study area has the potential to increase and maximize net profit. This agrees with the findings of Dhima and Dordas (2007), who found out that the return earned from the optimal plan exceed net return obtained from existing plan by $43 \%$.

\section{CONCLUSION AND RECOMMENDATION}

Most of the production inputs were not optimally utilized. The crop mixtures were in a better competitive position in the optimum plan than maize as a sole crop. Based on these findings, Farmers should adopt the optimum farm plans prescribed, that is, produce the crop mixtures maize/soybeans and maize/cowpea that fit into the plan based on their hectarage allocation. This would help them to achieve food security, increased farm income and reduced cost of production. Effective farm advisory services on efficient allocation of farm resources and appropriate cropping patterns should be incorporated into programs to promote increased agricultural productivity among farmers. Since labour is limiting in the study area, more labour should be employed in further crop production so as to make use of the other resources that were surplus in the study area.

\section{REFERENCES}

Akpan A.O., Udoh P.M. and Nkanta J.K. (2012). Optimal crop combinations under limited resources uses: application of linear goal programming model to small holder farmers in Abak, Akwa Ibom State of Nigeria. Cottingen Journal of Technological and Institution Innovation for Sustainable Rural Development, 17 (1), 8-10

Alhassan, H.A. (2017). Effect of Niger State Rice Investment Consortium Project on Commercialization Levels of Smallholder Farmers in Niger State, Nigeria. Unpublished MTech Thesis Submitted to the Department of Agricultural Economics and Extension Technology, Federal University of Technology, Minna, Nigeria
Angha M.S. and Itari M.M. (2012). Optimum Cropping pattern and resources allocation in a growing economy: a close model approach Bangladesh Journal of Agric. Economics XVIII, 2, 15-37

CBN (2007). Statement of Accounts 2007. Country Annual Report, Central Bank of Nigeria (CBN) Abuja, Nigeria

Chukwuji O.C. (2008). Comparative analysis of enterprise combination costs and returns in cassava-based food crop farming systems in Delta State, Nigeria. Asian Research Publishing Network (ARPN) Journal of Agricultural and Biological Science, 3 (4), 27-32

Dhima K.V. and Dordas C.A. (2007). Competition indices of common vetch and cereal intercrops in two seeding ratio. Field Crops Research, 100, 249-256

Fasasi A.R. (2007). Technical efficiency in food crop production in Oyo State, Nigeria. Journal of Human Ecology, 22 (3), 245-249

Hassan I., Ahmad B., Akhter M. and Aslam M. (2005). Use of linear cropping model to determine the optimum cropping pattern: a case study of Punjab. Electronic Journal of Environmental Agricultural and Food Chemistry, 4 (1), 841-850

Igwe K.C. and Onyenweaku C.E. (2013). A linear programming approach to food crops and livestock enterprises planning in Aba Agricultural Zone of Abia State, Nigeria. American Journal of Experimental Agriculture, 3 (2), 412-431

Ismail A.R. (2013). The Role of Irrigation in Poverty Alleviation: a Case Study of Fadama Development. M.Sc Thesis, Faculty of Agriculture, Usumanu Danfodio University, Sokoto, Nigeria, $105 \mathrm{pp}$

Kariaga B.M. (2004). Intercropping maize with cowpeas and beans for soil and water management in Western Kenya. ISCO 2004-13th International Soil Conservation Organisation Conference (pp. Paper No. 993, 1). Brisbane: Conserving Soil and Water for Society: Sharing Solutions

Mafimisebi T.E., Babalola O.M. and Mafimisebi O.E. (2013). Fundamentals of cattle marketing in Southwest, Nigeria: analyzing market intermediaries, price formation and yield performance. Invited Paper Presented at the $4^{\text {th }}$ International Conference of the African Association of Agricultural Economists, September 22-25, 2013, Hammamet, Tunisia

Nasiru M., Haruna U. and Garba A. (2012). Economics of livestock marketing in Gamawa Local Government Area, Bauchi State, Nigeria. 8th AFMA Congress, November 25-29, 2012, Nairobi, Kenya. No. 159412. African Farm Management Association (AFMA)

NBS (2012). The Review of the Nigerian Economy 2012 Edition. 57 pp. National Bureau of Statistics

NPC (2006). National and State Population and Housing Tables: 2006 Census Priority Tables Vol. 1. National Population Commission Available at: www.population.gov.ng/index/php/censuses 
Ogundari K. and Ojo S.O. (2007). Economic efficiency of small scale crop production in Nigeria: a stochastic frontier approach. Journal of Social Sciences, 14 (2), 123-130

Ojo S.O. (2003). Factor productivity in maize production in Ondo State, Nigeria. Journal of Applied Tropical Agriculture, 15 (1), 57-63

Olayemi J.K. and Onyenweaku C.E. (1999). Quantitative Methods for Business Decisions. Bosude Printers Limited, Ibadan, Nigeria. 346 pp.

Oviasogie D.I. (2005). Productivity of Yam-Based Farming System in Edo State, Nigeria. MSc Thesis, Department of Agricultural Economics, Federal University of Technology, Akure, $105 \mathrm{pp}$

Sallawu H. (2014). Livelihood and Income Diversification Strategies among Farm Households in Niger State, Nigeria. Unpublished MTech Thesis Submitted to the Department of Agricultural Economics and Extension Technology, Federal University of Technology, Minna, Nigeria

Sarker, R.A., \& Quaddus, M.A. (2002). Modelling a nationwide crop planning problem using a multiple criteria decision making tool. Computers \& Industrial Engineering, 42, 541-553

Seran T.H. and Brintha I. (2010). Review on maize based intercropping, Journal of Agronomy, 9 (3), 135-145
Singh B.M. (1989). Potential for increasing income on small farm. Proceedings of the National Seminar on Economic Revival of Small Farmers Held at University of Agriculture, Faisalabad, Pakistan, $4^{\text {th }}-5^{\text {th }}$ March. p136

Sofi N.A., Ahmed. A., Ahmad M. and Bhat B.A. (2015). Decision making in agriculture: a linear programming approach. International Journal of Modern Mathematical Sciences, 13 (2), 160-169

Subbarao G.V., Renard C.R., Payne W.A. and Bationo A.B. (2000). Long-term effects of tillage, phosphorus fertilization and crop rotation on pearl millet /cowpea productivity in West Africa. Exploratory Agriculture, 36, 243-264

UNFPA (2015). UNFPA in Niger State: population projections. United Nations Population Fund Retrieved from www.unfpa.org/Niger.HTML.10/07/2015

USDA (2012). Nigeria grain and feed annual 2012. United States Department of Agriculture http://www.thebioenergysite.com/report

Wankhade M.O. and Lunge H.S. (2012). Allocation of agricultural land to major crops of saline track by linear programming approach: a case study. International Journal of Scientific and Technology Research, 1 (9), 21-25 